Aquaculture

September 2015, Volume 446, Pages 111-121

http://dx.doi.org/10.1016/j.aquaculture.2015.04.029

http://archimer.ifremer.fr/doc/00266/37751/

(C) 2015 Elsevier B.V. All rights reserved

\title{
Mass selection for survival and resistance to OsHV-1 infection in Crassostrea gigas spat in field conditions: response to selection after four generations
}

\author{
Dégremont Lionel ${ }^{1 ? *}$, Nourry Max ${ }^{2}$, Maurouard Elise ${ }^{1}$ \\ ${ }^{1}$ SG2M, LGP2M, Ifremer, La Tremblade, France \\ ${ }^{2}$ SG2M, LSPC, Ifremer, Bouin, France \\ * Corresponding author : Lionel Dégremont, tel.: + 33546762630 ; fax: + 33546762611 ; \\ email address : lionel.degremont@ifremer.fr
}

\begin{abstract}
:
The ostreid herpesvirus 1 (OsHV-1) is one of the major pathogens affecting the Pacific oyster Crassostrea gigas, and numerous mortality outbreaks have been observed worldwide. We report the first results of our experimental breeding program using mass selection focused on survival and resistance to OsHV-1 after four generations of selection for two lines. These lines originated from two stocks of adult wild oysters sampled from the Marennes-Oléron Bay in 2008. Each line was spawned in February 2009 to produce the base populations. Both lines were then either protected from OsHV-1 or tested in the field in 2009 where they were exposed to OsHV-1. For each line during 2010 to 2013, one generation per year was produced using either the survivors of the previous generation for the selected group or the oysters protected from OsHV-1 for the control group. After one generation of selection (G1) for both lines, the mean survival of the selected group was $34.5 \%$ compared with $12.3 \%$ in the control group. For the fourth generation of selection (G4), the survival of the selected group reached $69.0 \%$ and the survival of the control group was $7.3 \%$. The gain in survival of the selected $C$. gigas spat over the control increased by $22.2 \%, 43.9 \%, 50.2 \%$ and $61.8 \%$ for the $\mathrm{G} 1, \mathrm{G} 2$, G3 and G4 generations, respectively. Our study demonstrates that mass selection for survival and OsHV-1 resistance was successful after four generations of selection, thus indicating a significant genetic improvement for the selected trait. A genotype $\mathrm{x}$ size interaction was observed with $55.1 \%$ of survival in $\mathrm{G} 4$ when selected spat were transferred at $1 \mathrm{~g}$ versus $89.9 \%$ of survival when they were transferred at $3 \mathrm{~g}$. Our study is the first to provide some estimates of the realized heritability for disease resistance using a mass selection scheme in an oyster species with values ranging from 0.34 to 0.63 depending on the size of the oysters exposed to OsHV-1. Oysters selected for their higher resistance to OsHV-1 infection in G4 showed higher growth $(58.4 \mathrm{~mm}-19.4 \mathrm{~g})$ than controls $(51.4 \mathrm{~mm}-15.2 \mathrm{~g})$, and mass selection had significantly improved the yield for the selected oysters $(13.3 \mathrm{~kg})$ over the controls $(1.2 \mathrm{~kg})$. Mass selection could be easily implemented by a commercial hatchery that cannot afford family-based selection that requires the production of numerous families for the base population.
\end{abstract}




\section{Highlights}

Mass selection to enhance survival and OsHV-1 resistance was successful in C. gigas spat. This is the first study to report realized heritability for disease resistance in an oyster species. The gain of survival per generation was $12.1 \%$ to $20.2 \%$ for $1 \mathrm{~g}$ and $>3 \mathrm{~g}$ oysters, respectively. The selected oysters grew faster and had a much higher yield than did the unselected oysters.

\section{Statement of relevance}

Strong impact on breeding program working on OsHV-1 resistance in C. gigas.

Keywords : survival, Crassostrea gigas, realized heritability, selection response, OsHV-1, disease resistance 


\section{Introduction}

Massive disease-related mortality has been commonly reported worldwide in several major oyster species. One striking example concerns the mortality outbreaks related to the ostreid herpesvirus OsHV-1 infecting the Pacific cupped oyster Crassostrea gigas. During the last decade, such outbreaks were reported on the west coast of the USA (Burge et al., 2006), in New Zealand and Australia (Paul-Pont et al., 2013; Keeling et al., 2014) and in numerous countries in Europe (EFSA, 2010; Lynch et al., 2012; Roque et al., 2012; Domeneghetti et al., 2014). In France, which is the main European producer of $C$. gigas, OsHV-1 has regularly affected cultivated spat and juvenile oysters for several years (Renault et al., 1994; Dégremont, 2003; Garcia et al., 2011). However, since 2008, dramatic mortality outbreaks related to OsHV-1 have routinely occurred in Crassostrea gigas in France (Ségarra et al., 2010; Pernet et al., 2012; Dégremont, 2013), leading to decreased French oyster production from to 111000 tons in 2008 to 82000 tons in 2012 (FAO, 2014). In addition to environmental degradation and naturally higher susceptibility of the oyster to disease, French cultural practices could have favored the disease propagation and settlement over time among all growing areas. This increase in mortality could also be related to a higher virulence of the virus with the description of the genotype called OsHV-1 $\mu$ var (Ségarra et al., 2010), which was previously found in Normandy in 2004 (Martenot et al., 2012). Unfortunately, no evidence has been provided thus far to show a difference in virulence among OsHV-1 genotypes, although many of these strains were identified during mortality outbreaks dating back to 1993 (Lynch et al., 2012; Martenot et al., 2012; Renault et al., 2012; Lynch et al., 2013; Martenot et al., 2013). Nevertheless, severe production losses due to OsHV-1 have been reported in France and are related to a microvariant that has taken over as the predominant strain. This situation urges researchers to develop strategies to reduce the mortality in C. gigas spat.

One approach to combat this problem is a selective breeding program to enhance disease resistance, and thus, the survival of $C$. gigas spat. A first approach showed that the oysters selected for their higher or lower resistance to the summer mortality phenomena in 2001 were found to be correspondingly resistant or susceptible to OsHV-1 infection during mortality outbreaks observed in 2002 and 2003 (Dégremont, 2003; Dégremont et al., 2010a). The same findings were observed with subsequent generations of the selected oysters that were tested from 2009 to 2012, pointing to an underlying genetic basis for resistance to OsHV-1 infection in C. gigas (Dégremont, 2011; Dégremont, 2013). These findings were based on family selection for which numerous families are produced to estimate the genetic parameters and to obtain families containing the desirable genetic traits. Nevertheless, most of commercial hatcheries in France cannot afford to raise and test numerous oyster families. As an alternative, mass selection is simpler and less expensive because only one selected group is produced along with a control group to assess whether changes are caused by genetic modification or environmental variation. This selection method relies on high fecundity in the shellfish, enabling the use of a higher selection intensity compared to that used for terrestrial livestock (Gjedrem and Baranski, 2009). Nevertheless, without individual tagging and pedigree records, this selection scheme could lead to inbreeding and thus reduce the response to selection (Bentsen and Olesen, 2002). However, mass selection without a true control for inbreeding has been widely used in shellfish species to enhance growth or disease resistance.

Numerous mass selection trials have focused on growth and survival traits. Estimation of a realized heritability is reported for growth-related traits in oysters, clams and scallop species 
(Toro and Newkirk, 1990; Hadley et al., 1991; Jarayabhand and Thavornyutikarn, 1995; Crenshaw et al., 1996; Toro et al., 1996; Ibarra et al., 1999; Zheng et al., 2004; He et al., 2008; Deng et al., 2009; Dobler and Hosken, 2009; Li et al., 2011; Zhao et al., 2012). Surprisingly, all studies regarding mass selection for survival related to disease resistance failed to provide such estimates, although a positive response to selection was always reported (Ford and Haskin, 1987; Naciri-Graven et al., 1998; Davis and Barber, 1999; Nell et al., 1999; Dove et al., 2013a; Frank-Lawale et al., 2014).

In our paper, we report our efforts to increase the survival of and resistance to OsHV-1 in $C$. gigas spat using mass selection by breeding disease survivors throughout four generations of selection. Enhanced survival as a result of this selection was investigated using two sizes of oyster, and the realized heritability for this trait was estimated for the first time in an oyster species. In addition, the growth parameters (individual shell height and individual whole weight) and yield (total weight of live oysters) were also recorded to estimate the effect that survival mass selection had on these important commercial traits.

\section{Materials and methods}

Five generations were produced in this study including one generation of multiplication using the wild oysters as parents and four generations of selection. To avoid confusion, the generations were numbered according to selection chronology as follows: $G_{0}$ for no selection, $\mathrm{G}_{1}$ for the first generation of selection and so on.

\subsection{Base population $\left(G_{0}\right)$}

Wild oysters were sampled from two oyster reefs at Agnas (45'52'23' 'N, $1^{\circ} 10^{\prime} 15^{\prime \prime} \mathrm{W}$ ) and at La Tremblade (4546'53" N, $1^{\circ} 7^{\prime} 19^{\prime \prime} \mathrm{W}$ ), both located in the Marennes-Oléron bay, in December 2008. We considered that the two oyster reefs were from the same genetic population, which was supported by a recent study that showed the lack of genetic differentiation between several French oyster populations (Rohfritsch et al., 2013). The two stocks of wild oysters constituted the parents of the base populations from which a mass selection on the basis of survival was carried out within each origin. The stock sampled at Agnas was named line A, and the stock sampled at La Tremblade was named line B. The two lines were placed in the conditioning room at the Ifremer hatchery in La Tremblade until spawning. The seawater temperature was gradually increased from ambient temperature to $21^{\circ} \mathrm{C}$ for one week, and the seawater was enriched with a cultured phytoplankton diet (Isochrysis galbana, Tetraselmis suecica and Skeletonema costatum) to favor gametogenesis.

Spawning occurred in February 2009 (Table 1). The oysters were opened, and those that were not ripe were discarded. The others were sexed using a microscope by spreading a small gonad tissue sample on a slide. For each parent, the gametes were collected by stripping the gonads, which were successively sieved to remove large $(>60 \mu \mathrm{m})$ and small $(<20 \mu \mathrm{m})$ tissues for the eggs and to remove only the large tissues for the sperm. For line A, seven males were each mated to a pool of eggs from 13 females, and for line B, 9 males were each mated to a pool of eggs from 21 females to produce the base population $\left(G_{0}\right)$ (Table 1). The methodology used for the larvae and spat cultures was as described by Dégremont et al. (2007). 
Each line was then assigned to one of two environments: (1) the $G_{0}-C A$ and $G_{0}-C B$ were held in our experimental facilities in La Tremblade and in Bouin to avoid disease-related mortality and to produce control (C) groups for the following generations, and (2) the $\mathrm{G}_{0}-\mathrm{SA}$ and $\mathrm{G}_{0}-\mathrm{SB}$ were exposed to OsHV-1 in field conditions where mortality outbreaks in the C. gigas spat populations have been reported (Fig. 1). The field deployment occurred during June 2009 (Table 2).

\subsection{First generation $\left(G_{1}\right)$}

Spawns occurred in March 2010 using the same protocols described for $\mathrm{G}_{0}$. Two groups were produced for each line: the control group (C) $\mathrm{G}_{1}-\mathrm{C}$ using $\mathrm{G}_{0}-\mathrm{C}$ group, and the selected group (S) $G_{1}-S$ using the survivors of the mortality outbreaks from the $G_{0}-S$ group. For line $A$, ten males were each mated to a pool of eggs from 17 females to produce the $G_{1}$-CA group, while 10 males were each mated to a pool of 21 females to produce the $G_{1}$-SA group (Table 1 ). The same approach was used for line $B$ by mating 13 males and 20 females to produce the $\mathrm{G}_{1}-\mathrm{CB}$ group and 4 males and 28 females to produce the $\mathrm{G}_{1}-\mathrm{SB}$ group (Table 1 ). For each line, control and selected groups were then deployed in the field four times during June, July, August and September 2010 (Table 2). Thus, $\mathrm{G}_{1}$-CA and $\mathrm{G}_{1}-\mathrm{SA} 1$ as well as $\mathrm{G}_{1}-\mathrm{CB}$ and $\mathrm{G}_{1^{-}}$ SB1 were tested in field conditions during the first deployment in June 2010 until October 2010 (Table 2). For the second deployment, $\mathrm{G}_{1}-\mathrm{CA}$ and $\mathrm{G}_{1}-\mathrm{SA} 2$ as well as $\mathrm{G}_{1}-\mathrm{CB}$ and $\mathrm{G}_{1^{-}}$ SB2 were tested in field conditions starting in July 2010 until October 2010 (Table 2), and so on until the fourth deployment (Table 2). Consequently, due to different dates of deployment, A1 to $A 4$ were pseudo replicates of the same $G_{1}$-SA spawn using survivors of the $G_{0}-S A$ from the line A selected group, and B1 to B4 were pseudo replicates from the same $G_{1}-S B$ spawn using survivors of the $\mathrm{G}_{0}$-SB from the line B selected group (Fig.1). This multiple deployment approach was used to strengthen the result for the response to selection and to investigate size-dependent responses of the oysters when exposed to OsHV-1 as it has been shown that larger oysters can exhibit greater disease resistance (Dégremont, 2011).

\subsection{Second to fourth generations $\left(G_{2}\right.$ to $\left.G_{4}\right)$}

Spawns occurred in February 2011, March 2012 and February 2013 for the $G_{2}, G_{3}$ and $G_{4}$, respectively (Table 1). For these generations, a pool of sperm was mated to a pool of eggs for each spawn. This process was different than that used for the two previous generations in which each male was mated to a pool of eggs. For each generation, two groups were also produced for each line, the control group $\mathrm{C}$ and the selected group $\mathrm{S}$. For the control group, 10 males and 14 females of the $\mathrm{G}_{1}$-CA group were mated to produce the $\mathrm{G}_{2}$-CA group for line A, whereas 11 males and 19 females of the $G_{1}$-CB group were mated to produce the $\mathrm{G}_{2}-\mathrm{CB}$ group (Fig. 1) (Table 1). In contrast to the $G_{1}-S$ groups, the $G_{2}-S$ groups for each line had four replicate spawns using different breeders from the $\mathrm{G}_{1}$-S groups, and so generating 4 sub-lines in the selected group. Thus, for line $A$, the survivors of the $G_{1}-S A 1$ were used to produce the $\mathrm{G}_{2}$-SA1, the survivors of the $\mathrm{G}_{1}$-SA2 were used to produce the $\mathrm{G}_{2}$-SA2, the survivors of the $\mathrm{G}_{1}$-SA3 were used to produce the $\mathrm{G}_{2}$-SA3 and finally, survivors of the $\mathrm{G}_{1}$-SA4 were used to produce the $\mathrm{G}_{2}$-SA4 (Fig. 1). The same approach was used for line $B$, which also contained four sub-lines spawns named $G_{2}-S B 1$ to $G_{2}-S B 4$. For the subsequent generations $G_{3}$ and $G_{4}$, one control per line was produced, and each sub-line, A1 to A4 and B1 to B4, was generated using survivors of the previous generation (Fig. 1). To summarize, five spawns using different spawners (one control $\mathrm{C}$ and four selected sub-lines $\mathrm{S}$ ) were produced for each line from the $\mathrm{G}_{2}$ to $\mathrm{G}_{4}$. Each spawn involved an average of 11 males and nine females, and the exact number of males and females for each spawn are provided in Table 1 along with the 
inbreeding rate throughout all generations and spawns. As was done for $\mathrm{G}_{1}$, all groups were deployed into the field four times during the summer season on a monthly basis from May to October (Table 2). For example, $\mathrm{G}_{2}-\mathrm{SA} 1$ to $\mathrm{A} 4$ and $\mathrm{G}_{2}-\mathrm{SB} 1$ to $\mathrm{B} 4$ along with their respective controls were deployed on 05/31/11, 07/07/11, 08/03/11, and 09/01/11. As indicated in the previous section, this approach of multiple oyster deployments was utilized to investigate the response to selection when exposed to OsHV-1 according to oyster size. Finally, the oysters used to produce the subsequent generation from the selected group were only those assessed during the first field deployment. Thus, for the selected group from line $A$, the $G_{4}-S$ A1 was produced from the $\mathrm{G}_{3}-\mathrm{S}$ A1 deployed on $06 / 20 / 12$, which was produced from the $\mathrm{G}_{2}-\mathrm{S} A 1$ deployed on 05/31/11 (Table 2) (Fig. 1). This strategy is explained by the low survival for this deployment, which increased the intensity of selection.

\subsection{Field testing}

For the second year in a row, mortality outbreaks related to OsHV-1 were observed along the entire French coast in 2009. Consequently, regulatory rules had forbidden oyster transfers between growing areas in the spring of 2009. As a result, the oysters could not be tested in our experimental farms located at Agnas in the Marennes-Oléron Bay as they were grown at the Ifremer nursery located in Bouin in the Bourgneuf Bay. As an alternative, we decided to test the $\mathrm{G}_{0}$-S oysters in an interdital area in front of the nursery in the Bourgneuf Bay (46 ${ }^{\circ} 56^{\prime 2} 26^{\prime \prime}$ $\left.\mathrm{N}, 2^{\circ} 7^{\prime} 10^{\prime \prime} \mathrm{W}\right)$. For each line, one bag (7 mm mesh size, $100 \mathrm{x} 55 \mathrm{~cm}$ ) containing $2 \mathrm{~kg}$ of spat (mean individual weight of $1 \mathrm{~g}$ ) was deployed in the interdital area where many other oyster farms surrounded our experimental farm. Mortality was recorded one month post-deployment as a check point and three months later as an endpoint (Table 2). The total weight of the live oysters at the endpoint date was recorded, giving the yield as the product of survival and growth.

The selected groups and control groups from each line spanning $G_{1}$ to $G_{4}$ were tested at the Ifremer experimental farm located at Agnas in the Marennes-Oléron Bay. For each deployment, two bags ( $7 \mathrm{~mm}$ mesh size, 100 x27 cm) per spawn containing 150 oysters each were tested, and the mean individual weight of the oysters ranged from 1 to $11 \mathrm{~g}$ (Table 3). The total weight of the live oysters was recorded at deployment and at the endpoint dates to estimate the yield, which was standardized to $1 \mathrm{~kg}$ of spat tested. The mortality was recorded in the fall, but an additional check-up was conducted one month post-deployment for some trials (Table 2). In addition to survival, 30 oysters per spawn were individually measured for shell height (in millimeters) and weight (in grams) at deployment and at the endpoint for $\mathrm{G}_{4}$. The number of oysters was of course reduced for spawns showing heavy mortality at the endpoint. From 2010 to 2013, the seawater temperature was recorded using a YSI probe \#6600 to monitor environmental fluctuations in the Pertuis Charentais (SAPERCHAIS/LERPC).

\subsection{Detection and quantification of OsHV-1}

No groups showed disease mortality prior to deployment, and OsHV-1 DNA had never been detected in any of the animals (several hundred) sampled from our hatchery and nursery prior to their deployment since 2008 (Dégremont and Benabdelmouna, 2014; Pernet et al., 2014). Thus, disease sampling was only focused on the period two weeks post-deployment when the first moribund oysters were observed, and this corresponded to the onset of mortality outbreaks related to OsHV-1 when C. gigas spat are deployed during the risk period when seawater temperatures is above $16^{\circ} \mathrm{C}$ (Pernet et al., 2012; Dégremont, 2013). Twelve 
moribund oysters were sampled either in the $\mathrm{S}$ or $\mathrm{C}$ groups at two weeks post-deployment for the first deployment of all generations except for $G_{3}$. We focused on the first deployment as survivors of the selected group were used to produce the following generations. Detection and quantification of OsHV-1 DNA was carried out for each of the individual oysters using the $\mathrm{SYBR}^{\circledR}$ green real-time PCR protocol as described by Pépin et al. (2008) adapted for use with DPFor/DPRev primers to target the OsHV-1 DNA polymerase sequence (ORF 100). The results were expressed as the viral DNA copy number per mg of oyster tissue.

\subsection{Data analyses}

Statistical analyses are only presented for data collected at the endpoint. All statistics were performed using the SAS ${ }^{\circledR} 9.4$ software.

\subsubsection{Survival}

A comparison of the survival between the $\mathrm{C}$ and $\mathrm{S}$ groups was analyzed within line and within generation for each deployment date by a binomial logistic regression using the GENMOD procedure with the following model:

$\operatorname{Logit}\left(Y_{i l}\right)=\mu_{i}$

For $\mathrm{G}_{4}$, we fitted a complete model as follows:

$\operatorname{Logit}\left(Y_{i j k l}\right)=\mu_{i}+\mu_{j}+\mu_{k}+\mu_{i} \times \mu_{j}+\mu_{i} \times \mu_{k}+\mu_{k} \times \mu_{j}+\mu_{i} \times \mu_{k} \times \mu_{j}$

where $Y_{i l}$ and $Y_{i j k l}=$ the observed survival at the endpoint for oyster $l$ in group $i$ (control or selected) from line $j$ (A or B) tested at deployment $k$ (1 to 4). All effects and their interactions were fixed. When a significant interaction was observed, the SLICE option was used. This approach allows for a more powerful analysis than rerunning the model for each effect because the degrees of freedom are not reduced (Littell et al., 2002).

\subsubsection{Estimation of the realized heritability of survival}

This experiment is a mass selection based on a threshold trait. Thus, the survival trait is a function of an underlying variable, which is the level of resistance of the oyster to OsHV-1 infection, hereafter called the liability. Therefore, all oysters possessing a level of resistance to OsHV-1 infection higher than the threshold will survive, while the others will die. Unfortunately, this threshold is not fixed and is decreased for larger oyster size and to a lesser extent for older oysters (Dégremont, 2013). Additionally, the threshold could also vary according to field conditions, which is an uncontrolled environmental variable. However, the $\mathrm{C}$ (control) group produced for each generation in each line allowed us to assess the effects of changing environmental conditions during the course of the experiment (Roff, 1997). The response to selection was the difference in survival between the selected group and their respective controls within generations on the liability scale. The selection differential was the mean liability of the selected parents in the previous generation as it deviated from the mean liability of the population, given the intensity of selection $i$ as reported in Appendix Table A by Falconer and Mackay (1996). The cumulative selection differential was then the sum of the selection differential for each generation. The realized heritability was estimated within and among the lines as the slope of the response to selection to the cumulative selection differential, which was forced through the origin for both selected and controls derived from 
the same base population (Falconer and Mackay, 1996; Roff, 1997). The standard error of the realized heritability was the standard error of the slope from the simple linear regression, which was estimated by the REG procedure with the NOINT option. In detail, the data used for the estimation of the realized heritability are represented in bold and italics in Table 3, and correspond to the realized heritability to increased survival and OsHV-1 resistance for oysters having an average size of $1 \mathrm{~g}$ when exposed to the disease (only the survivors of the first deployment of $G_{2}$ and $G_{3}$ were used to produce the subsequent generation). In addition, the realized heritability was also estimated using the survival data obtained for the last deployment of $\mathrm{G}_{4}$, which could be interpreted as an oyster size greater than $3 \mathrm{~g}$.

\subsubsection{Yield and growth}

For yield and growth, only the results of the first deployment of the last generation $\mathrm{G}_{4}$ were analyzed to focus on the potential effect of mass selection to improve oyster survival and resistance to OsHV-1 infection. Meanwhile, similar results were observed in the other deployments and in the earlier generations of selection (data not shown).

The yield, which was defined as the total weight of the live oysters at the endpoint, was standardized for $1 \mathrm{~kg}$ of spat tested, log transformed and analyzed using the GLM procedure by running an ANOVA using the following model:

$\log \left(Y_{i j k l}\right)=\mu+\mu_{i}+\mu_{j}+\mu_{i} \mathrm{x} \mu_{j}+\mu_{k(i j)}+\varepsilon_{i j k l}$

where $\mu$ is the intercept, $\mu_{i}$ and $\mu_{j}$ are the fixed effect of the line (A or B) and group (control or selected), respectively, $\mu_{k(i j)}$ is the random variation in the bag, and $\varepsilon_{i j k l}$ is the error term.

Similarly, the length and weight data were log transformed and analyzed using the GLM procedure by running an ANCOVA with time as a covariate.

\section{Results}

\subsection{Seawater temperature}

The seawater temperature in the Bourgneuf Bay was greater than $16^{\circ} \mathrm{C}$ during the field testing period in the Bourgneuf Bay. At Agnas, the seawater temperature from June 2010 to October 2013 is shown in Fig. 2 and was above $16^{\circ} \mathrm{C}$ during at least three weeks post-deployment for all deployment periods and generations, except the last deployment of $G_{3}$ in which the seawater temperature rapidly decreased below $16^{\circ} \mathrm{C}$ at the end of October 2012 (Fig. 2).

\subsection{Detection and quantification of OsHV-1}

For all generations, except for the $\mathrm{G}_{3}$ for which no disease sample was obtained, OsHV-1 DNA was detected in all moribund oysters sampled during the peak of mortality. The viral load was high and exceeded $10^{+6}$ DNA copies per mg of fresh oyster tissue. 


\subsection{Survival}

The onsets of mortality outbreaks were always observed within the two weeks postdeployment, except for the last $\mathrm{G}_{3}$ deployment on October $2^{\text {nd }}, 2012$. When possible, comparison of the mortality recorded one month post-deployment with those recorded during the fall indicated that $90 \%$ of the cumulative mortality occurred during the first month postdeployment (data not shown).

At the endpoint, the survival for both lines of the base population $\mathrm{G}_{0}$ was low, with $8.9 \%$ for line A and $22.4 \%$ for line B (Table 3).

For the $\mathrm{G}_{1}$, the mean survival of the control group during each of the four deployments was again low with $4.7 \%$ and $19.9 \%$ for lines $A$ and $B$, respectively, while it was $41.8 \%$ and $27.1 \%$ for the selected group (Table 3). For both lines, the survival of the selected group was significantly higher than that the control $(P<0.0001)$, except for the two last deployments of line $B$ (Table 3). For the following generation $G_{2}$, the mean survival for the four deployments remained low for the control group with $11.0 \%$ and $18.3 \%$ for lines $A$ and $B$, respectively. In contrast, the mean survival of the selected group was higher in $G_{2}$ than in $G_{1}$ with $55.2 \%$ and $61.8 \%$ for lines A and B, respectively. Within deployment and within line, the survival of the selected group was higher than the survival of the control group $(\mathrm{P}<0.0001)$.

For the $\mathrm{G}_{3}$ excluding the last deployment due to the absence of mortality, the mean survival of the control group was $8.7 \%$ and $5.6 \%$ for lines A and B, respectively, and $49.7 \%$ and $64.9 \%$ for the selected group (Table 3). Within deployment and within line, the survival of the selected group was higher than the survival of the control group $(\mathrm{P}<0.0001)$.

For the $\mathrm{G}_{4}$, the mean survival of the control group for the four deployments was still low with $6.3 \%$ and $8.3 \%$ for lines $\mathrm{A}$ and $\mathrm{B}$, respectively, while it was higher for the selected group with $65.5 \%$ and $72.6 \%$, respectively (Table 3 ). The overall survival analysis for $\mathrm{G}_{4}$ revealed the presence of a significant group by deployment interaction $(\mathrm{P}=0.04)$ (Table 4). At the group level, the selected group had a higher survival for the last deployment $(\mathrm{P}<0.0001)$, while the control group had a similar survival whenever they were deployed in the field $(\mathrm{P}=0.46)$ (Tables 3 and 4). No significant interaction was found between the group and the line $(\mathrm{P}=$ 0.87), and survival was found to be similar between lines $(P=0.18)$. In contrast, a significant difference in survival was found between groups, with the highest survival for the selected group and the lowest survival for the control group $(\mathrm{P}<0.0001)$ (Table 4).

Overall, the survival across deployments of the selected group increased from $41.8 \%$ to $59.2 \%$ for the line A from the G1 to G4 respectively, and from $27.1 \%$ to $72.6 \%$ for the line B while survival of the control group never exceeded $11.0 \%$ and $19.9 \%$ for lines A and B respectively (Table 3) 
For a 1-g oyster exposed to OsHV-1, the survival of the selected group over the survival of the control group regularly increased from $+12.0 \%$ and $+16.3 \%$ for lines $\mathrm{A}$ and $\mathrm{B}$, respectively in the $\mathrm{G} 1$ the $\mathrm{G}_{1}$ to $+43.9 \%$ and $+52.4 \%$ in the $\mathrm{G}_{4}$ (Table 5). At each generation, the survival increased by $11.0 \%$ for line A and $13.1 \%$ for line B (Table 5). The realized heritability after four generations of mass selection to enhance survival in $C$. gigas spat, i.e., resistance to OsHV-1 infection, was moderate, with $\mathrm{h}^{2}=0.34 \pm 0.05$ for line $\mathrm{A}, \mathrm{h}^{2}=0.52 \pm$ 0.03 for line $\mathrm{B}$ and $\mathrm{h}^{2}=0.41 \pm 0.03$ for both lines (Fig. 3ABC). With regards to the response to selection for larger oysters ( $>3 \mathrm{~g}$ ), the gain of survival of the $\mathrm{G}_{1}$ was high for the line $A$ with $+59.8 \%$, while it was weak for the line B with $+2.8 \%$. Meanwhile, both lines showed high gains in survival in $\mathrm{G}_{4}$ with $+80.2 \%$ and $+80.6 \%$ for lines $A$ and $B$, respectively. The gains in survival per generation for oysters $>3 \mathrm{~g}$ was higher than for 1 -g oysters at $20.2 \%$ (Table 5). The realized heritability estimated using the data from the last deployment of $\mathrm{G}_{4}$ revealed higher estimates than using the data of the first deployment of $G_{4}$ with $h^{2}=0.46 \pm$ 0.05 for line $A, h^{2}=0.63 \pm 0.04$ for line $B$ and $h^{2}=0.52 \pm 0.03$ for both lines (Table 5).

\subsection{Yield and growth}

For the first deployment of $\mathrm{G}_{4}$, the mean individual shell height and weight for both lines at deployment were $17.7 \mathrm{~mm}$ and $1.0 \mathrm{~g}$ for the control group, respectively, and $17.1 \mathrm{~mm}$ and 0.9 $\mathrm{g}$ for the selected group. At the endpoint on October $8^{\text {th }}, 2013$, the mean individual shell height of the control group was $51.4 \mathrm{~mm}$, and it was significantly lower than the mean individual shell height of the selected group at $58.4 \mathrm{~mm}$ (Fig. 4A) (Table 6). The same result was also observed for the whole oyster weight with a gain of $4 \mathrm{~g}$ for the selected group (19.4 g) over the control group (15.2 g) (Fig. 4B). The interaction between groups and lines was not significant, and both lines showed similar growth trends for both traits (Table 6).

The mean standardized yield, which is the total weight of all live oysters at the endpoint for 1 $\mathrm{kg}$ of spat tested, of each line and each group for the first deployment of $\mathrm{G}_{4}$ in 2013 is presented in Fig. 4C. For $1 \mathrm{~kg}$ of spat deployed on May 29 $9^{\text {th }}$, 2013, the standardized yield of the control group on October $8^{\text {th }}$, 2013 was $1.1 \mathrm{~kg}$ and $1.3 \mathrm{~kg}$ for lines A and B, corresponding to increases of $10 \%$ and $30 \%$, respectively. In contrast, the standardized yield of the selected group was $11.5 \mathrm{~kg}$ and $15.0 \mathrm{~kg}$ for lines A and B, respectively. A significant difference in yield was found between groups $(P<0.0001)$, and all other effects were not significant (Table 7).

\section{Discussion}

This study was conducted in the field at Agnas in the Marennes-Oléron Bay, where, in addition to OsHV-1, other pathogens or factors could have been involved in the mortality observed in our oysters. Meanwhile, the onset and kinetics of mortality combined with the high amount of OsHV-1 DNA found in moribund oyster tissues strongly supports that OsHV1 could be considered as the main factor of the mortality outbreaks observed each year from 2009 to 2013. Furthermore, OsHV-1 is considered to be the main cause of mortality in $C$. 
gigas when viral load exceeds $10^{+5}$ DNA copies per mg of fresh oyster tissue (Pépin et al., 2008; Sauvage et al., 2009; Oden et al., 2011; Schikorski et al., 2011).

Whatever the generation and the deployment, the survival of the control groups was usually lower than 20\%, indicating that OsHV-1 was very active during the course of the experiment. For both lines and all deployments, survival of the selected C. gigas spat increased by $22.2 \%$, $43.9 \%, 50.2 \%$ and $61.8 \%$ for $\mathrm{G}_{1}, \mathrm{G}_{2}, \mathrm{G}_{3}$ and $\mathrm{G}_{4}$, respectively, indicating that selection for resistance to OsHV-1 was successful (Table 3). These values are in the range obtained for other mass selection trials for survival to enhance disease resistance in oysters, such as resistance to Martelia sydneyi (QX disease) in Saccostrea glomerata (Nell and Hand, 2003; Nell and Perkins, 2006; Dove, et al., 2013a) and resistance to Haplosporidium nelsoni in C. virginica (Ford and Haskin, 1987).

Upon closer inspection, the mean gain of survival per generation ranged from $11.0 \%$ to $13.1 \%$ for oysters weighing $1 \mathrm{~g}$, indicating that the mean survival of selected oysters could jump from $20 \%$ to $64-72 \%$ in only four generations of selection, which used to be the survival routinely observed in wild-caught C. gigas spat before 2008 in the Marennes-Oléron Bay (Mille et al., 2014). More interestingly, the size of the oysters when they were exposed to OsHV-1 had a significant impact on the response to selection, which was twice as much per generation for oysters heavier than $3 \mathrm{~g}$ in comparison with those weighing $1 \mathrm{~g}$ (Table 5). It was demonstrated that larger unselected $C$. gigas spat, and to a much lesser extent older oysters, are less susceptible to the disease than are the smaller spat, with a positive relationship between survival and size: $13 \%, 20 \%$ and $30 \%$ for oysters weighing $1 \mathrm{~g}, 5 \mathrm{~g}$ and $10 \mathrm{~g}$, respectively (Dégremont, 2013). This finding suggest a higher resistance to the disease in larger oysters considering that the threshold did not change between sizes, allowing a higher proportion of oysters to survive. The underlying mechanisms of such resistance are still unknown. Consequently, in addition to selection, a culture strategy on oyster farms to maximize the survival against OsHV-1 could easily be implemented as already described (Dégremont, 2013) and was first described during the summer mortality phenomena during 2001-2003 (Dégremont et al., 2010c). One of these strategies could involve deployment of the selected C. gigas spat after the threat of exposure to OsHV-1 to utilize a site and cultural practices that favor rapid growth, and thus, promote the response to selection.

As the selection was completed using oysters weighing $1 \mathrm{~g}$ when exposed to OsHV-1 with the exception of the $G_{2}$, which used $G_{1}$ parents from each deployment (see Table 3), it is interesting to note that the gain in survival was higher for line B than for line A (Table 5). The hypothesis to explain this finding relied on a founder population effect. Indeed, the survival of the $\mathrm{G}_{0}$ was higher for line $\mathrm{B}$ than line A indicating a higher resistance to OsHV-1 for line B as early as the $G_{0}$. Thus, genetic resistance was more rapidly developed in line $B$, even if the gain did not increase between $G_{3}$ and $G_{4}$ in contrast to line A (Table 5). Still, the gain of survival is expected to decrease for the following generations due to the decreased intensity of selection resulting in a higher survival rate of the selected oysters. However, even if all selected oysters were resistant to OsHV-1, survival of the selected group will reach a threshold that should be undeniably lower than $100 \%$.

It is also worth noting that the mean gain in survival for the four deployments was quite similar between lines $A$ and $B$ from $G_{2}$ to $G_{4}$, but different in the $G_{1}$ with a mean gain in survival of $37.1 \%$ in line A compared with $7.2 \%$ in line B (Table 3 ). In a closer inspection of the data, this result is explained by a much higher survival of the $\mathrm{G}_{1}$-SA3 $(63.0 \%)$ and $\mathrm{G}_{1^{-}}$ SA4 (70.3\%) while their corresponding controls still had low survival (<9\%) (Table 3). The 
selected group of line A was able to develop OsHV-1 resistance in a very short period of time, and to date, this increase in size and age related to a sudden increase in resistance remains unexplained.

Our study is the first to report findings concerning the response to mass selection for survival and resistance to OsHV-1 infection in C. gigas spat. Furthermore, the realized heritability was estimated after four generations of selection to obtain an accurate estimate of heritability and to avoid the response of a single generation, which is frequently very variable (Roff, 1997). The realized heritability for OsHV-1 resistance estimated for oysters weighing $1 \mathrm{~g}$ when exposed to OsHV-1 was moderate, ranging from 0.34 to 0.52 , and increased from 0.46 to 0.63 for larger oysters (Table 5). These results strongly support that a breeding program to enhance survival and OsHV-1 resistance would be successful due to a significant additive genetic variance. Unfortunately, there is not any value in comparing $C$. gigas to other oyster species because all mass selection for disease resistance failed to provide such estimates. Meanwhile, our estimates of realized heritability for OsHV-1 resistance in C. gigas spat are in agreement with those obtained for survival of this species in France (narrow sense heritabilities at 6 months of age ranged from 0.47 to 1.08; Dégremont et al., 2007, 2010b), on the West Coast of USA ( $h^{2}$ broad sense at 6 months of age $=0.49-0.71$; Evans and Langdon, 2006), in Japan $\left(\mathrm{h}^{2}\right.$ narrow sense at 1 year of age $=0.77$; Usuki, 2002) and in Australia $\left(\mathrm{h}^{2}\right.$ at 21 months of age = 0.68; Ward et al., 2005). However, all results were not related to OsHV-1 infection due to the absence of disease sampling, but it is worth noting that OsHV-1 is present in all of these countries (Burge, et al., 2006; Garcia, et al., 2011; Shimahara et al., 2012; Jenkins et al., 2013). This was strongly supported through a similar mortality data for C. gigas spat in France obtained before and after 2008. Indeed, the same oyster families were tested, and OsHV-1 was detected in moribund oysters during several mortality outbreaks for all of the generations produced between 2001 and 2003. This suggested that OsHV-1 could have been one of the main causes of the summer mortality phenomenon for which the high heritability (narrow and realized) for survival in the C. gigas spat was found (Dégremont, et al., 2007; Dégremont, et al., 2010b).

Although there are no data to compare with other oyster species, the heritability of disease resistance has been reported in other important aquaculture species. Several studies reported low heritability such as the White Spot Syndrome Virus in shrimps (Gitterle et al., 2006; Cock et al., 2009), but others reported moderate to high heritability for disease resistance and/or survival in fish species (Henryon et al., 2005; Ødegård et al., 2007; Gjerde et al., 2009; Taylor et al., 2009). Our study is in agreement with those reporting high genetic variation for disease resistance and such findings seems common in aquatic species as suggested by Gjedrem and Baranski (2009) and confirmed for example by a recent review on disease resistance in salmonid species with heritability for resistance to Aeromonas salmonicida in Salmo salar ranging from 0.34 to 0.62 (Yáñez et al., 2014).

Our experimental breeding program is one strategy, along with family selection, mostly used by the French commercial hatcheries to enhance OsHV-1 resistance in C. gigas spat. Despite the fact that mass selection to improve survival of $C$. gigas spat was successful, it was done without a true control at the inbreeding level. Although the inbreeding level ranged from 0.13 to 0.15 after four generations of selection (Table 1), the true inbreeding rate is expected to be much higher. There is a high variance in reproductive success in the Pacific oyster, which was attributed to the gamete quality, sperm-egg interaction and differential viability among genotypes (Boudry et al., 2002). Their study also showed a $20 \%$ decrease of the effective population size under sperm competition, as done in our study from $G_{2}$ to $G_{4}$, in comparison 
to no sperm competition, as done in our study for the $G_{0}$ and $G_{1}$. Our selection was made on survival by selecting OsHV-1-resistant oysters using high intensity of selection due to low survival rate of the selected oysters for both lines in $G_{0}$ and to a lesser extent for the other generations (Table 3). Simulations showed that the rate of inbreeding was higher when the heritability was high because a higher heritability increases the similarity between full-sib progeny and consequently increases the probability of selecting full-sibs as broodstock (Bentsen and Olesen, 2002). This is particularly true in fish and shellfish species with very high fecundity, such as $C$. gigas, which produce several millions eggs and billions of sperm. This may have quickly produced highly inbred lines because only a few parents are needed to reproduce each generation (Gjedrem and Baranski, 2009). Consequently, the moderate realized heritability ( 0.34 for line A and 0.52 for line B - Table 5 ) combined with the high intensity of selection and the high fecundity of oysters may have reduced the response to selection, and thus, the realized heritability.

Selection to improve survival and resistance to OsHV-1 resistance was successful after four generations of mass selection in C. gigas spat. The impact of selection on other growth traits was assessed for the first deployment of $\mathrm{G}_{4}$ and was shown in this study. For both lines, the oysters of the control groups had a lower whole weight and lower shell height than did the selected groups (Fig. 4ab), suggesting that selection to improve resistance to OsHV-1 infection did not reduce but rather increased growth. Genetic correlations between growth and survival of the summer mortality phenomenon, for which OsHV-1 was highly suspected to be implicated, were null or low but positive, which could explain our results (Dégremont, et al., 2007). Similar results were also observed for the previous generations and latter deployments, but the data were not shown for the clarity of this paper. However, such traits should be recorded until market size is reached to confirm the lack of a negative relationship between survival and growth, but the results reported during the first year were already encouraging. Nevertheless, other studies investigating the growth and survival related to disease resistance until market size is reached never showed a lower growth of the selected lines over the controls, as observed for resistance to Perkinsus marinus and $H$. nelsoni in C. virginica (Frank-Lawale, et al., 2014), or for resistance to Bonamia roughleyi and $M$. sydneyi in $S$. glomerata (Dove, et al., 2013a; Dove et al., 2013b). Once again, care must be taken regarding the correlation between growth and survival related to disease resistance, as the breeders might also have been selected for growth too, such as in S. glomerata for which the breeding program was originally focused on mass selection of the largest individual growth before incorporating selection for QX resistance (Nell et al., 2000).

More interestingly, the yield of the selected groups was 10- to 15-fold higher than the yield of the control (Fig. 4c). Similar findings were observed for the same time period and using diploid and triploid oysters selected for their higher resistance to OsHV-1 after the mortality outbreak (Dégremont et al., 2014). As the yield is hugely affected by survival in sites where mortality outbreaks are reported whereas it is growth in sites without mortality (Evans and Langdon, 2006; Dégremont, et al., 2010b; Dégremont et al., 2012), selection to improve disease resistance will automatically improve the yield of the oysters. Meanwhile, such high performance of the selected groups (survival and growth) would result in splitting the oyster bag quite rapidly in order to not lose this advantage due to bag overcrowding, which was attained in our study at the endpoint. If not done, the selected oysters will reduce or stop their growth, and the correlation between growth and survival will switch from positive to negative due to inappropriate culturing practices. 
In conclusion, our study clearly demonstrates that mass selection for survival and OsHV-1 resistance was successful after four generations of selection, indicating a significant genetic improvement for the selected trait. The gain per generation of selection was $12.1 \%$ for oysters weighing $1 \mathrm{~g}$ when exposed to OsHV-1, and the gain was almost twice as much for oysters heavier than $3 \mathrm{~g}$ at $20.2 \%$. Our study is the first to provide estimates of the realized heritability for disease resistance using a mass selection scheme in an oyster species, with values ranging from 0.34 to 0.63 , depending on the oyster size. Apparently, selection for resistance to OsHV-1 infection in our study improved growth in comparison with the controls, and this selection automatically improved the yield of C. gigas, which was 10- to 15-fold in our study. Mass selection could then be easily implemented by a commercial hatchery that cannot afford family-based selection that involves the production of numerous families for the base population.

\section{Acknowledgments}

We wish to thank the hatchery, nursery and genetic teams of the Laboratory of Genetics and Pathology of Ifremer La Tremblade and Ifremer Bouin for their assistance in oyster production, as well as Jean Luc Seugnet for his help in field operations. We also acknowledge Florence Rivet for her help with bibliographic research and the Laboratory of Environment and Resources of the Pertuis Charentais, Ifremer La Tremblade, for the temperature dataset collection that was performed from the monitoring of environmental fluctuations in the Pertuis Charentais (SAPERCHAIS/LERPC). We greatly acknowledge the oyster farmer Gérard Billon for providing the study site and a boat for field operations. This work was entirely funded by Ifremer.

We would like to thank the three anonymous reviewers for their comments to improve this manuscript.

\section{References}

Bentsen, H.B., Olesen, I., 2002. Designing aquaculture mass selection programs to avoid high inbreeding rates. Aquaculture 204, 349-359.

Boudry, P., Collet, B., Cornette, F., Hervouet, V., Bonhomme, F., 2002. High variance in reproductive success of the Pacific oyster (Crassostrea gigas, Thunberg) revealed by microsatellite-based parentage analysis of multifactorial crosses. Aquaculture 204, 283-296.

Burge, C.A., Griffin, F.J., Friedman, C.S., 2006. Mortality and herpesvirus infections of the Pacific oyster Crassostrea gigas in Tomales Bay, California, USA. Diseases of Aquatic Organisms 72, 31-43.

Cock, J., Gitterle, T., Salazar, M., Rye, M., 2009. Breeding for disease resistance of Penaeid shrimps. Aquaculture 286, 1-11. 
Crenshaw, J.W., Heffernan, P.B., Walker, R.L., 1996. Effect of growout density on heritability of growth rate in the northern quahog, Mercenaria mercenaria (Linnaeus, 1758). Journal of Shellfish Research 15, 341-344.

Davis, C.V., Barber, B.J., 1999. Growth and survival of selected lines of eastern oysters, Crassostrea virginica (Gmelin 1791) affected by juvenile oyster disease. Aquaculture 178, 253-271.

Dégremont, L., 2003. Etude des bases génétiques de la mortalité estivale et des relations avec la croissance chez les juvéniles de Crassostrea gigas. Université de Caen Basse Normandie, Caen, pp. 333.

Dégremont, L., 2011. Evidence of herpesvirus (OsHV-1) resistance in juvenile Crassostrea gigas selected for high resistance to the summer mortality phenomenon. Aquaculture 317, 94-98.

Dégremont, L., 2013. Size and genotype affect resistance to mortality caused by OsHV-1 in Crassostrea gigas. Aquaculture 416-417, 129-134.

Dégremont, L., Ernande, B., Bedier, E., Boudry, P., 2007. Summer mortality of hatcheryproduced Pacific oyster spat (Crassostrea gigas). I. Estimation of genetic parameters for survival and growth. Aquaculture 262, 41-53.

Dégremont, L., Soletchnik, P., Boudry, P., 2010a. Summer mortality of selected juvenile Pacific oyster Crassostrea gigas under laboratory conditions and in comparison with field performance. Journal of Shellfish Research 29, 847-856.

Dégremont, L., Bédier, E., Boudry, P., 2010b. Summer mortality of hatchery-produced Pacific oyster spat (Crassostrea gigas). II. Response to selection for survival and its influence on growth and yield. Aquaculture 299, 21-29.

Dégremont, L., Boudry, P., Ropert, M., Samain, J.-F., Bédier, E., Soletchnik, P., 2010c. Effects of age and environment on survival of summer mortality by two selected groups of the Pacific oyster Crassostrea gigas. Aquaculture 299, 44-50

Dégremont, L., Garcia, C., Frank-Lawale, A., Allen, S.K., 2012. Triploid oysters in the Chesapeake Bay: comparison of diploid and triploid Crassostrea virginica. Journal of Shellfish Research 31, 21-31.

Dégremont, L., Benabdelmouna, A., 2014. Mortality associated with OsHV-1 in spat Crassostrea gigas: role of wild-caught spat in the horizontal transmission of the disease. Aquaculture International 22, 1767-1781

Dégremont, L., Ledu, C., Maurouard, E., Nourry, M., Benabdelmouna, A., 2014. Effect of ploidy on the mortality of Crassostrea gigas spat caused by OsHV-1 in France using unselected and selected OsHV-1 resistant oysters. Aquaculture Research, n/a-n/a.

Deng, Y.W., Fu, S., Du, X.D., Wang, Q.H., 2009. Realized heritability and genetic gain estimates of larval shell length in the Chinese pearl oyster Pinctada martensii at three different salinities. North American Journal of Aquaculture 71, 302-306.

Dobler, R., Hosken, D.J., 2009. Response to selection and realized heritability of sperm length in the yellow dung fly (Scathophaga stercoraria). Heredity 104, 61-66.

Domeneghetti, S., Varotto, L., Civettini, M., Rosani, U., Stauder, M., Pretto, T., Pezzati, E., Arcangeli, G., Turolla, E., Pallavicini, A., Venier, P., 2014. Mortality occurrence and pathogen detection in Crassostrea gigas and Mytilus galloprovincialis close-growing in shallow waters (Goro lagoon, Italy). Fish \& Shellfish Immunology 41, 37-44.

Dove, M.C., Nell, J.A., O'Connor, W.A., 2013a. Evaluation of the progeny of the fourthgeneration Sydney rock oyster Saccostrea glomerata (Gould, 1850) breeding lines for resistance to QX disease (Marteilia sydneyi) and winter mortality (Bonamia roughleyi). Aquaculture Research 44, 1791-1800.

Dove, M.C., Nell, J.A., McOrrie, S., O'Connor, W.A., 2013b. Assessment of Qx and winter mortality disease resistance of mass selected Sydney rock oysters, Saccostrea 
glomerata (Gould, 1850), in the Hawkesbury River and Merimbula Lake, NSW Australia. Journal of Shellfish Research 32, 681-687.

EFSA, 2010. Scientific opinion on the increased mortality events in Pacific oysters, Crassostrea gigas. EFSA journal 8, 1-60.

Evans, S., Langdon, C., 2006. Effects of genotype x environment interactions on the selection of broadly adapted Pacific oysters (Crassostrea gigas). Aquaculture 261, 522-534.

Falconer, D.S., Mackay, T.F.C., 1996. Introduction to quantitative genetics, Fourth edition ed. Addison Wesley Longman, Essex, UK.

FAO, Fisheries and aquaculture software. FishStatJ - software for fishery statistical time series. FAO Fisheries and Aquaculture Department Rome http://www.fao.org/fishery/statistics/software/fishstatj/en, 2014

Ford, S.E., Haskin, H.H., 1987. Infection and mortality patterns in strains of oysters Crassostrea virginica selected for resistance to the parasite Haplosporidium nelsoni (MSX). Journal of Parasitology 73, 368-376.

Frank-Lawale, A., Allen, S.K., Dégremont, L., 2014. Breeding and domestication of Eastern oyster (Crassostrea virginica) lines for culture in the mid-Atlantic, Usa: line development and mass selection for disease resistance. Journal of Shellfish Research 33, 153-165.

Garcia, C., Thebault, A., Dégremont, L., Arzul, I., Miossec, L., Robert, M., Chollet, B., Francois, C., Joly, J.-P., Ferrand, S., Kerdudou, N., Renault, T., 2011. Ostreid herpesvirus 1 detection and relationship with Crassostrea gigas spat mortality in France between 1998 and 2006. Veterinary Research 42, 73.

Gitterle, T., Gjerde, B., Cock, J., Salazar, M., Rye, M., Vidal, O., Lozano, C., Erazo, C., Salte, R., 2006. Optimization of experimental infection protocols for the estimation of genetic parameters of resistance to White Spot Syndrome Virus (WSSV) in Penaeus (Litopenaeus) vannamei. Aquaculture 261, 501-509.

Gjedrem, T., Baranski, M., 2009. Selective breeding in aquaculture an introduction. Springer, London.

Gjerde, B., Evensen, Ø., Bentsen, H.B., Storset, A., 2009. Genetic (co)variation of vaccine injuries and innate resistance to furunculosis (Aeromonas salmonicida) and infectious salmon anaemia (ISA) in Atlantic salmon (Salmo salar). Aquaculture 287, 52-58.

Hadley, N.H., Dillon, R.T., Manzi, J.J., 1991. Realized heritability of growth rate in the hard clam Mercenaria mercenaria. Aquaculture 93, 109-119.

He, M., Guan, Y., Yuan, T., Zhang, H., 2008. Realized heritability and response to selection for shell height in the pearl oyster Pinctada fucata (Gould). Aquaculture Research 39, 801-805.

Henryon, M., Berg, P., Olesen, N.J., Kjær, T.E., Slierendrecht, W.J., Jokumsen, A., Lund, I., 2005. Selective breeding provides an approach to increase resistance of rainbow trout (Onchorhynchus mykiss) to the diseases, enteric redmouth disease, rainbow trout fry syndrome, and viral haemorrhagic septicaemia. Aquaculture 250, 621-636.

Ibarra, A.M., Ramirez, J.L., Ruiz, C.A., Cruz, P., Avila, S., 1999. Realized heritabilities and genetic correlation after dual selection for total weight and shell width in catarina scallop (Argopecten ventricosus). Aquaculture 175, 227-241.

Jarayabhand, P., Thavornyutikarn, M., 1995. Realized heritability estimation on growth rate of oyster, Saccostrea cucullata Born, 1778. Aquaculture 138, 111-118.

Jenkins, C., Hick, P., Gabor, M., Spiers, Z., Fell, S.A., Gu, X.N., Read, A., Go, J., Dove, M., O'Connor, W., Kirkland, P.D., Frances, J., 2013. Identification and characterisation of an ostreid herpesvirus-1 microvariant (OsHV-1 mu-var) in Crassostrea gigas (Pacific oysters) in Australia. Diseases of Aquatic Organisms 105, 109-126. 
Keeling, S.E., Brosnahan, C.L., Williams, R., Gias, E., Hannah, M., Bueno, R., McDonald, W.L., Johnston, C., 2014. New Zealand juvenile oyster mortality associated with ostreid herpesvirus 1-an opportunistic longitudinal study. Diseases of Aquatic Organisms 109, 231-239.

Li, Q., Wang, Q., Liu, S., Kong, L., 2011. Selection response and realized heritability for growth in three stocks of the Pacific oyster Crassostrea gigas. Fisheries Science 77, 643-648.

Littell, R.C., Stroup, W.W., Freund, R.J., 2002. SAS® for Linear Models, Fourth Edition ed. SAS Institute Inc., Cary, NC.

Lynch, S.A., Carlsson, J., Reilly, A.O., Cotter, E., Culloty, S.C., 2012. A previously undescribed ostreid herpes virus 1 (OsHV-1) genotype detected in the pacific oyster, Crassostrea gigas, in Ireland. Parasitology 139, 1526-1532.

Lynch, S. A., Dillane, E., Carlsson, J., Culloty, S.C., 2013. Development and assessment of a sensitive and cost-effective polymerase chain reaction to detect Ostreid herpesvirus1 and variants. Journal of Shellfish Research 32, 657-664.

Martenot, C., Fourour, S., Oden, E., Jouaux, A., Travaille, E., Malas, J.P., Houssin, M., 2012. Detection of the OsHV-1 mu Var in the Pacific oyster Crassostrea gigas before 2008 in France and description of two new microvariants of the Ostreid Herpesvirus 1 (OsHV-1). Aquaculture 338, 293-296.

Martenot, C., Travaille, E., Lethuillier, O., Lelong, C., Houssin, M., 2013. Genome exploration of six variants of the Ostreid Herpesvirus 1 and characterization of large deletion in OsHV-1 mu Var specimens. Virus Research 178, 462-470.

Mille, D., Oudot, G., A., G., Geay, A., Barré, M., 2014. Observatoire ostréicole du littoral Charentais. Bilan de l'année 2013. Centre régional d'expérimentation et d'application aquacole, pp. 8.

Naciri-Graven, Y., Martin, A.G., Baud, J.P., Renault, T., Gérard, A., 1998. Selecting the flat oyster Ostrea edulis (L.) for survival when infected with the parasite Bonamia ostreae. Journal of Experimental Marine Biology and Ecology 224, 91-107.

Nell, J.A., Hand, R.E., 2003. Evaluation of the progeny of second-generation Sydney rock oyster Saccostrea glomerata (Gould, 1850) breeding lines for resistance to QX disease Marteilia sydneyi. Aquaculture 228, 27-35.

Nell, J.A., Perkins, B., 2006. Evaluation of the progeny of third-generation Sydney rock oyster Saccostrea glomerata (Gould, 1850) breeding lines for resistance to QX disease Marteilia sydneyi and winter mortality Bonamia roughleyi. Aquaculture Research 37, 693-700.

Nell, J.A., Smith, I.R., Sheridan, A.K., 1999. Third generation evaluation of Sydney rock oyster Saccostrea commercialis (Iredale and Roughley) breeding lines. Aquaculture 170, 195-203.

Nell, J.A., Smith, I.R., McPhee, C.C., 2000. The Sydney rock oyster Saccostrea glomerata (Gould 1850) breeding programme: progress and goals. Aquaculture Research 31, 4549.

Oden, E., Martenot, C., Berthaux, M., Travaille, E., Malas, J.P., Houssin, M., 2011. Quantification of ostreid herpesvirus 1 (OsHV-1) in Crassostrea gigas by real-time PCR: Determination of a viral load threshold to prevent summer mortalities. Aquaculture 317, 27-31.

Ødegård, J., Olesen, I., Gjerde, B., Klemetsdal, G., 2007. Positive genetic correlation between resistance to bacterial (furunculosis) and viral (infectious salmon anaemia) diseases in farmed Atlantic salmon (Salmo salar). Aquaculture 271, 173-177. 
Paul-Pont, I., Dhand, N.K., Whittington, R.J., 2013. Spatial distribution of mortality in Pacific oysters Crassostrea gigas: reflection on mechanisms of OsHV-1 transmission. Diseases of Aquatic Organisms 105, 127-138.

Pépin, J.F., Riou, A., Renault, T., 2008. Rapid and sensitive detection of ostreid herpesvirus 1 in oyster samples by real-time PCR. Journal of Virological Methods 149, 269-276.

Pernet, F., Barret, J., Le Gall, P., Corporeau, C., Dégremont, L., Lagarde, F., Pépin, J.F., Keck, N., 2012. Mass mortalities of Pacific oysters Crassostrea gigas reflect infectious diseases and vary with farming practices in the Mediterranean Thau lagoon, France. Aquaculture Environment Interactions 2, 215-237.

Pernet, F., Lagarde, F., Le Gall, P., D'Orbcastel, E.R., 2014. Associations between farming practices and disease mortality of Pacific oyster Crassostrea gigas in a Mediterranean lagoon. Aquaculture Environment Interactions 5, 99-106.

Renault, T., Ledeuff, R.M., Cochennec, N., Maffart, P., 1994. Herpesviruses associated with mortalities among Pacific oyster, Crassostrea gigas, in France - Comparative study. Revue De Medecine Veterinaire 145, 735-742.

Renault, T., Moreau, P., Faury, N., Pepin, J.F., Segarra, A., Webb, S., 2012. Analysis of clinical Ostreid herpesvirus 1 (Malacoherpesviridae) specimens by sequencing amplified fragments from three virus genome areas. Journal Of Virology 86, 59425947.

Roff, D.A., 1997. Evolutionary quantitative genetics, New York.

Rohfritsch, A., Bierne, N., Boudry, P., Heurtebise, S., Cornette, F., Lapègue, S., 2013. Population genomics shed light on the demographic and adaptive histories of European invasion in the Pacific oyster, Crassostrea gigas. Evolutionary Applications 6, 1064-1078.

Roque, A., Carrasco, N., Andree, K.B., Lacuesta, B., Elandaloussi, L., Gairin, I., Rodgers, C.J., Furones, M.D., 2012. First report of OsHV-1 microvar in Pacific oyster (Crassostrea gigas) cultured in Spain. Aquaculture 324, 303-306.

Sauvage, C., Pépin, J.F., Lapègue, S., Boudry, P., Renault, T., 2009. Ostreid herpes virus 1 infection in families of the Pacific oyster, Crassostrea gigas, during a summer mortality outbreak: Differences in viral DNA detection and quantification using realtime PCR. Virus Research 142, 181-187.

Schikorski, D., Renault, T., Saulnier, D., Faury, N., Moreau, P., Pepin, J.-F., 2011. Experimental infection of Pacific oyster Crassostrea gigas spat by ostreid herpesvirus 1: demonstration of oyster spat susceptibility. Veterinary Research 42, 27.

Segarra, A., Pépin, J.F., Arzul, I., Morga, B., Faury, N., Renault, T., 2010. Detection and description of a particular Ostreid herpesvirus 1 genotype associated with massive mortality outbreaks of Pacific oysters, Crassostrea gigas, in France in 2008. Virus Research 153, 92-99.

Shimahara, Y., Kurita, J., Kiryu, I., Nishioka, T., Yuasa, K., Kawana, M., Kamaishi, T., Oseko, N., 2012. Surveillance of Type 1 Ostreid Herpesvirus (OsHV-1) Variants in Japan. Fish Pathology 47, 129-136.

Taylor, R.S., Kube, P.D., Muller, W.J., Elliott, N.G., 2009. Genetic variation of gross gill pathology and survival of Atlantic salmon (Salmo salar L.) during natural amoebic gill disease challenge. Aquaculture 294, 172-179.

Toro, J.E., Newkirk, G.F., 1990. Divergent selection for growth rate in the European oyster Ostrea edulis: response to selection and estimation of genetic parameters. Marine Ecology Progress Series 62, 219-227.

Toro, J.E., Aguila, P., Vergara, A.M., 1996. Spatial variation in response to selection for live weight and shell length from data on individually tagged Chilean native oysters (Ostrea chilensis Philippi, 1845). Aquaculture 146, 27-36. 
Usuki, H., 2002. Evaluation of characteristics and preservation of Pacific oyster, Crassostrea gigas, in view of the genetic resources. Bulletin of Fisheries Research Agency (Japan), 40-104.

Ward, R.D., Thompson, P.A., Appleyard, S.A., Swan, A.A., Kube, P.D., 2005. Sustainable genetic improvement of Pacific oysters in Tasmania and South Australia. Final report FDRC Project 2000/2006. CSIRO Marine and Atmospheric Research and Fisheries Research and Development Corporation, Hobart (Tasmania), pp. 193.

Yáñez, J.M., Houston, R., Newman, S., 2014. Genetics and genomics of disease resistance in salmonid species. Front. Genet. 5:415. doi:10.3389/fgene.2014.00415

Zhao, L., Yan, X., Huo, Z., Yang, F., Zhang, G., 2012. Divergent selection for shell Length in the manila clam, Ruditapes philippinarum. Journal of the World Aquaculture Society 43, 878-884.

Zheng, H., Zhang, G., Liu, X., Zhang, F., Guo, X., 2004. Different responses to selection in two stocks of the bay scallop, Argopecten irradians irradians Lamarck (1819). Journal of Experimental Marine Biology and Ecology 313, 213-223. 


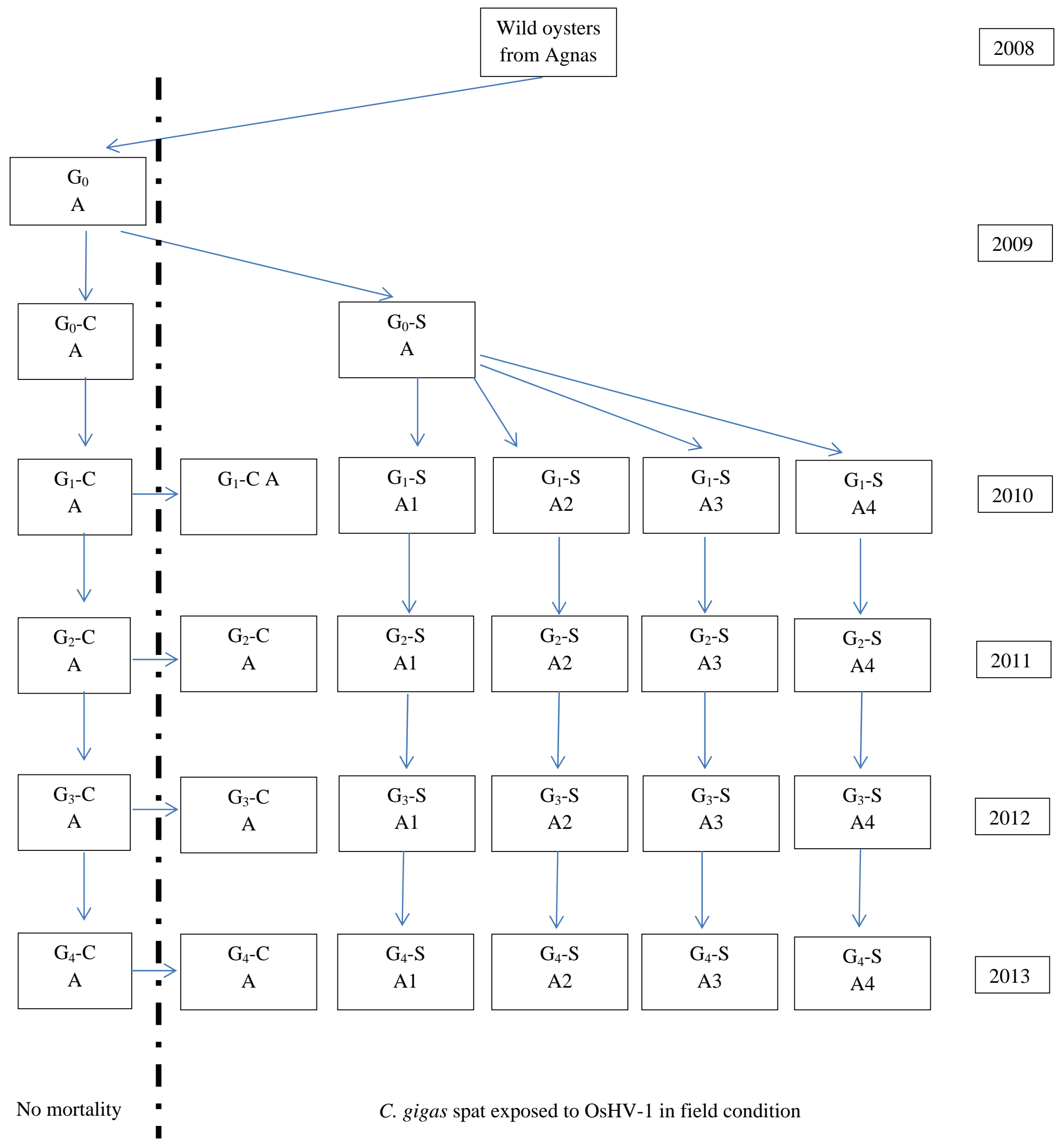

Fig. 1: Summary of the production of the selected (S) and control (C) groups of line A bred from wild oysters sampled at Agnas in the Marennes-Oléron Bay in 2008 (the same approach was used for line B but using wild oysters sampled at La Tremblade). 


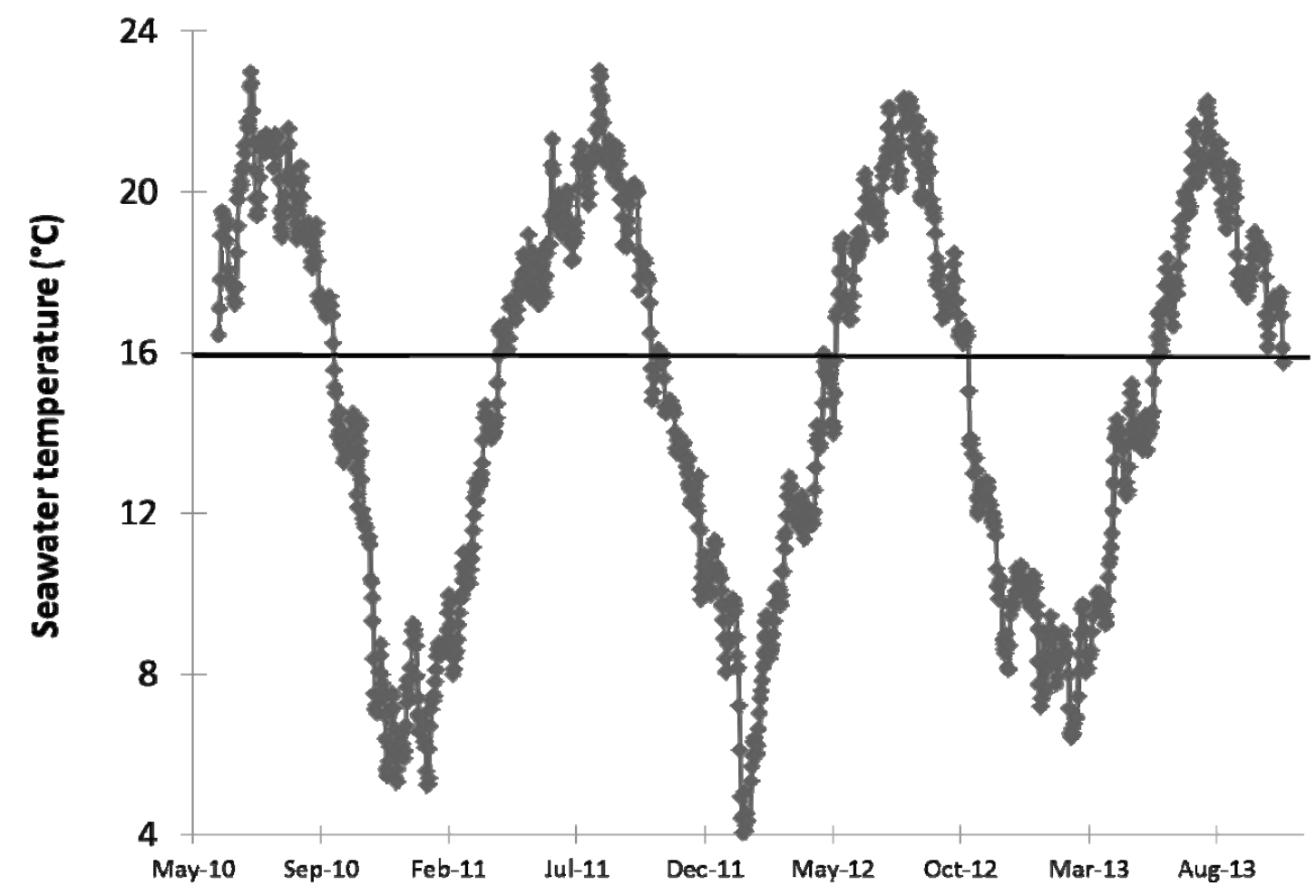

Fig. 2: Seawater temperature $\left({ }^{\circ} \mathrm{C}\right)$ at Agnas from June 2010 to October 2013. The horizontal line represents the threshold of $16^{\circ} \mathrm{C}$, beyond which mortality related to OsHV-1 is usually observed in our experimental field. 

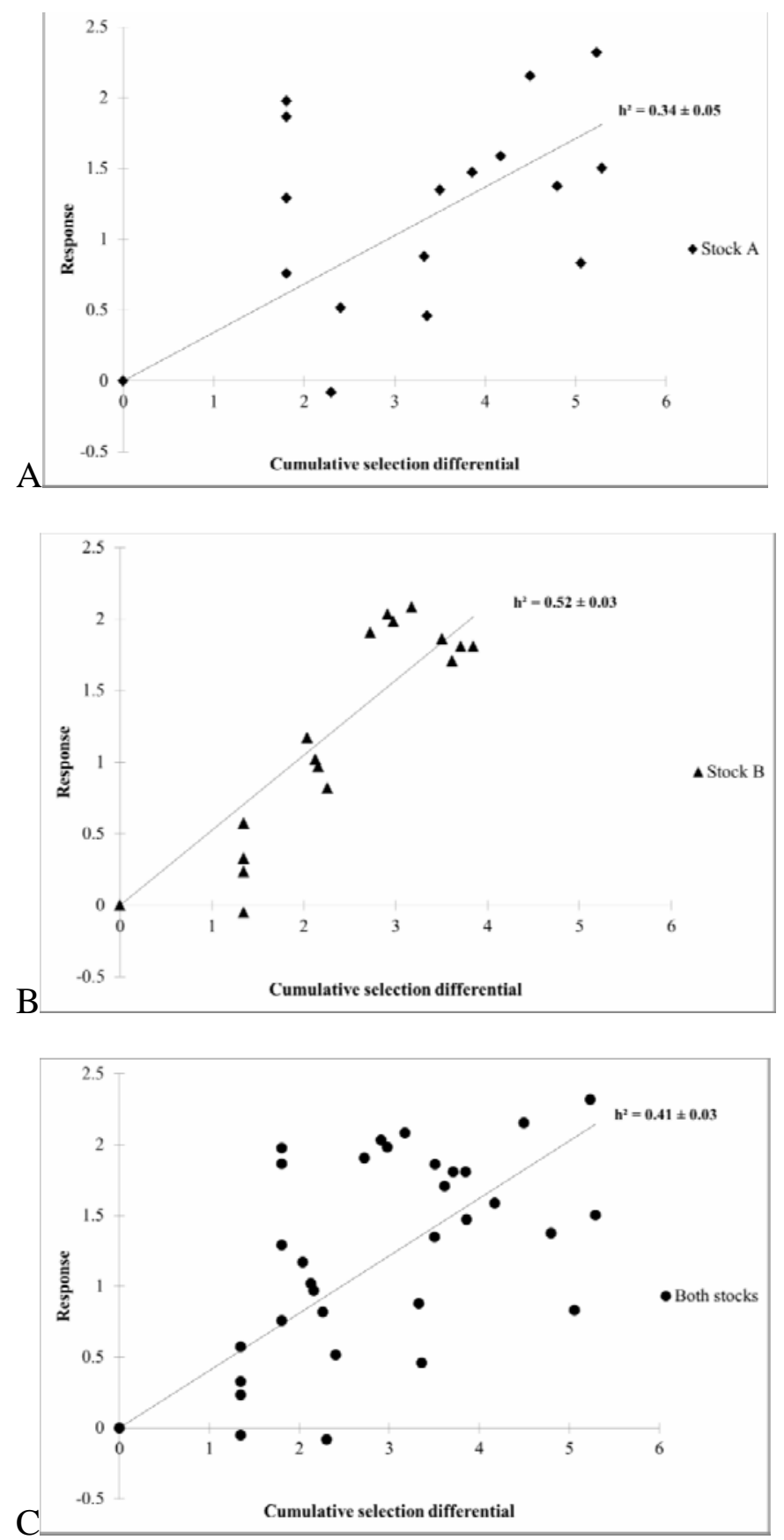

Fig. 3: Realized heritability (slope of the cumulative response according to the cumulative selection differential) to increase survival and resistance to OsHV-1 in C. gigas spat for each line (A \& B) and both lines (C) for a size of $1 \mathrm{~g}$ when exposed to the disease. 

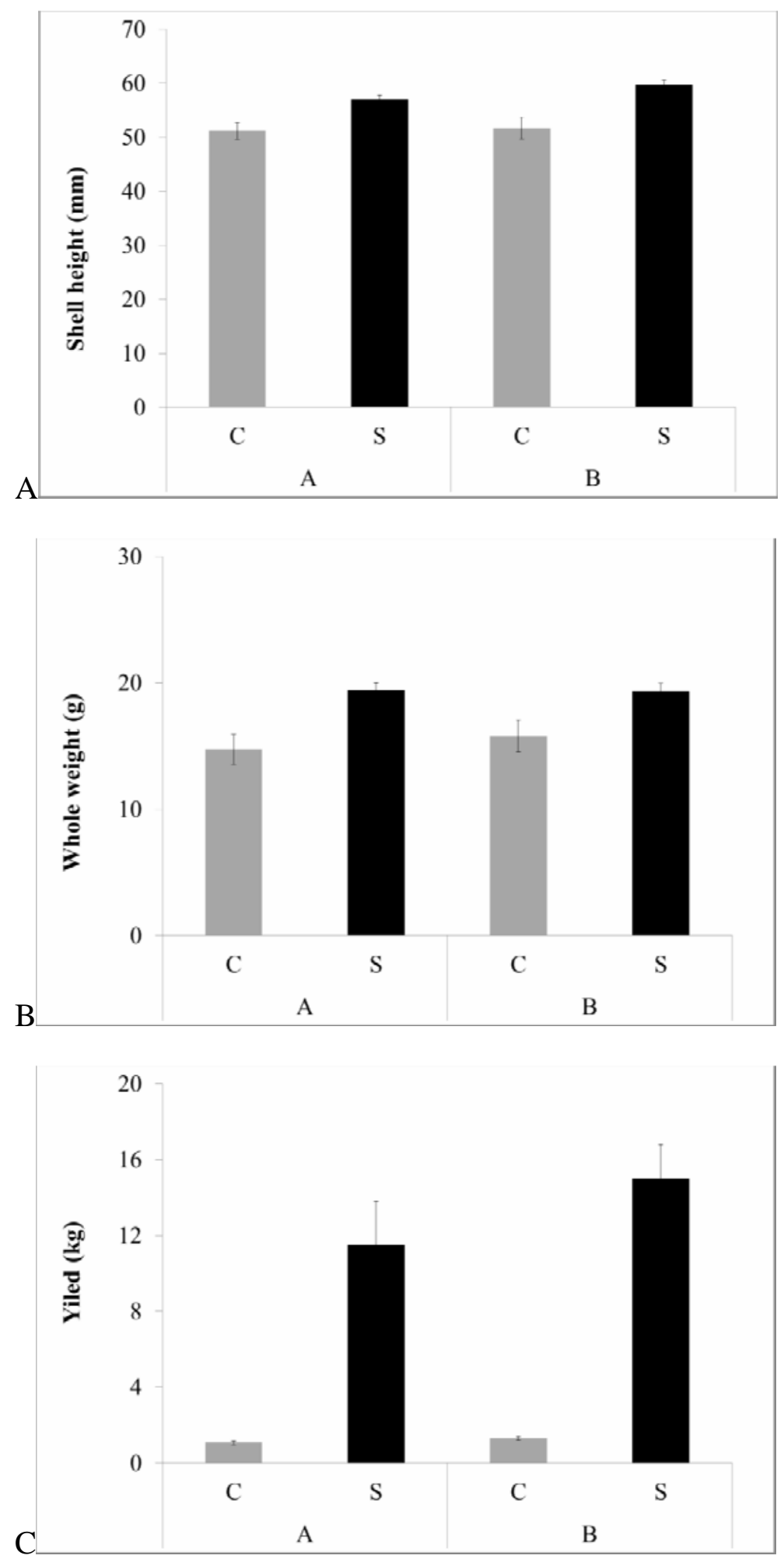

Fig. 4: Mean individual shell height (mm) (Fig. A), oyster weight (g) (Fig. B) and yield (kg) (Fig. $\mathrm{C}$ ) of the control ( $\mathrm{C}$ in grey) and selected ( $\mathrm{S}$ in black) groups for both lines for the first deployment of $\mathrm{G}_{4}$ at Agnas in October 2013. The yield is given for $1 \mathrm{~kg}$ of spat deployed on May 29th, 2013, and errors bars represent the SE. 
Table 1 Summary of the production of each spawn, date of the spawn, number of females (Nf) and males (Nm), effective size (Ne) and rate of inbreeding (F) in both groups (control $\mathrm{C}$ and selected $\mathrm{S}$ ) and both lines (line $\mathrm{A}$ and line B) from $\mathrm{G}_{0}$ to $\mathrm{G}_{4}$

\begin{tabular}{|c|c|c|c|c|c|c|c|c|c|c|c|c|c|}
\hline \multirow[b]{2}{*}{ Generation } & \multirow[b]{2}{*}{$\begin{array}{c}\text { Spawn } \\
\text { date }\end{array}$} & \multirow[b]{2}{*}{ Groups } & \multirow[b]{2}{*}{ Replicate $^{\mathrm{a}}$} & \multicolumn{5}{|c|}{ Line A } & \multicolumn{5}{|c|}{ Line B } \\
\hline & & & & $\mathrm{Nf}$ & $\mathrm{Nm}$ & $\mathrm{Ne}^{\mathrm{b}}$ & $\Delta \mathrm{F}^{\mathrm{c}}$ & $\mathrm{F}^{\mathrm{d}}$ & Nf & $\mathrm{Nm}$ & $\mathrm{Ne}^{\mathrm{b}}$ & $\Delta \mathrm{F}^{\mathrm{c}}$ & $\mathrm{F}^{\mathrm{d}}$ \\
\hline $\mathrm{G}_{0}$ & $02 / 23 / 09$ & & & 13 & 7 & 18.2 & 0.03 & 0.03 & 21 & 9 & 25.2 & 0.02 & 0.02 \\
\hline \multirow[t]{2}{*}{$\mathrm{G}_{1}$} & 03/15/10 & $\mathrm{C}$ & $X$ & 17 & 10 & 25.2 & 0.02 & 0.05 & 20 & 13 & 31.5 & 0.02 & 0.04 \\
\hline & & $\mathrm{S}$ & $X$ & 21 & 10 & 27.1 & 0.02 & 0.05 & 28 & 4 & 14.0 & 0.04 & 0.05 \\
\hline \multirow[t]{5}{*}{$\mathrm{G}_{2}$} & 02/01/11 & $\mathrm{C}$ & $X$ & 14 & 10 & 23.3 & 0.02 & 0.07 & 19 & 11 & 27.9 & 0.02 & 0.05 \\
\hline & & $\mathrm{S}$ & $\mathrm{X} 1$ & 7 & 14 & 18.7 & 0.03 & 0.07 & 7 & 7 & 14.0 & 0.04 & 0.09 \\
\hline & & $\mathrm{S}$ & $\mathrm{X} 2$ & 3 & 16 & 10.1 & 0.05 & 0.09 & 8 & 7 & 14.9 & 0.03 & 0.09 \\
\hline & & $\mathrm{S}$ & X3 & 8 & 6 & 13.7 & 0.04 & 0.08 & 5 & 12 & 14.1 & 0.04 & 0.09 \\
\hline & & $\mathrm{S}$ & X4 & 7 & 10 & 16.5 & 0.03 & 0.07 & 8 & 8 & 16.0 & 0.03 & 0.08 \\
\hline \multirow[t]{5}{*}{$\mathrm{G}_{3}$} & 03/05/12 & $\mathrm{C}$ & $\mathrm{X}$ & 18 & 12 & 28.8 & 0.02 & 0.08 & 23 & 5 & 16.4 & 0.03 & 0.08 \\
\hline & & $\mathrm{S}$ & $\mathrm{X} 1$ & 8 & 22 & 23.5 & 0.02 & 0.09 & 18 & 16 & 33.9 & 0.01 & 0.10 \\
\hline & & $\mathrm{S}$ & $\mathrm{X} 2$ & 9 & 15 & 22.5 & 0.02 & 0.09 & 8 & 10 & 17.8 & 0.03 & 0.11 \\
\hline & & $\mathrm{S}$ & X3 & 13 & 11 & 23.8 & 0.02 & 0.09 & 9 & 11 & 19.8 & 0.03 & 0.11 \\
\hline & & $\mathrm{S}$ & $\mathrm{X} 4$ & 7 & 16 & 19.5 & 0.03 & 0.09 & 6 & 22 & 18.9 & 0.03 & 0.11 \\
\hline \multirow[t]{5}{*}{$\mathrm{G}_{4}$} & 02/12/13 & $\mathrm{C}$ & $X$ & 6 & 21 & 18.7 & 0.03 & 0.11 & 10 & 20 & 26.7 & 0.02 & 0.10 \\
\hline & & $\mathrm{S}$ & $\mathrm{X} 1$ & 4 & 11 & 11.7 & 0.04 & 0.13 & 5 & 5 & 10.0 & 0.05 & 0.15 \\
\hline & & $\mathrm{S}$ & $\mathrm{X} 2$ & 5 & 6 & 10.9 & 0.05 & 0.13 & 10 & 3 & 9.2 & 0.05 & 0.15 \\
\hline & & $\mathrm{S}$ & X3 & 5 & 8 & 12.3 & 0.04 & 0.13 & 6 & 8 & 13.7 & 0.04 & 0.13 \\
\hline & & $\mathrm{S}$ & $\mathrm{X} 4$ & 5 & 6 & 10.9 & 0.05 & 0.13 & 5 & 10 & 13 & 0.04 & 0.14 \\
\hline
\end{tabular}

\footnotetext{
${ }^{\mathrm{a}}$ The letter $\mathrm{X}$ should be replaced by the name of the line, either ' $\mathrm{A}$ ' or 'B'. For the line A, the first replicate spawn of the selected group of the $\mathrm{G}_{2}$-SA 1 used 7 females and 14

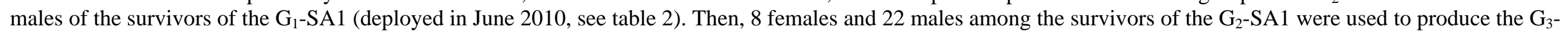
SA1, and finally, 4 females and 11 males among the survivors of the $G_{3}$-SA1were used to produce the $G_{4}-S A 1$.

${ }^{\mathrm{b}} \mathrm{Ne}$ is the effective size calculated as $\mathrm{Ne}=4 \mathrm{Nf} \mathrm{Nm} /(\mathrm{Nf}+\mathrm{Nm})$ (Falconer and Mackay, 1996),

${ }^{c} \Delta \mathrm{F}=1 / 2 \mathrm{Ne}$ is the new inbreeding of the $t(0$ to 4$)$ generation,

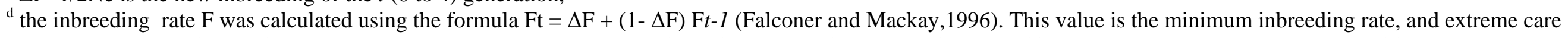

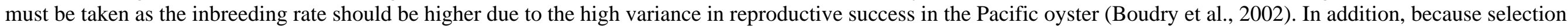
was made on the basis of survival by selecting OsHV-1 resistant oysters, and it is probable that some of them may be close relatives.
} 
Table 2 Summary of the key dates (MM/DD/YY) for the field testing at each generation.

\begin{tabular}{|c|c|c|c|c|c|c|}
\hline \multirow[b]{2}{*}{ Generation } & \multirow[b]{2}{*}{ Line } & \multicolumn{5}{|c|}{ Field testing } \\
\hline & & Deployment $^{\mathrm{a}}$ & Groups tested $^{b}$ & Start date & Check date & End date \\
\hline $\mathrm{G}_{0}$ & A \& B & 1 & SX & 06/09/09 & 07/08/09 & 09/06/09 \\
\hline \multirow[t]{4}{*}{$\mathrm{G}_{1}{ }^{\mathrm{c}}$} & A \& B & 1 & CX \& S X1 & $06 / 15 / 10$ & 07/13/10 & $10 / 20 / 10$ \\
\hline & & 2 & CX \& S X2 & 07/13/10 & 08/09/10 & $10 / 20 / 10$ \\
\hline & & 3 & CX \& S X3 & 08/11/10 & 09/10/10 & $10 / 20 / 10$ \\
\hline & & 4 & CX \& S X4 & 09/07/10 & & $10 / 20 / 10$ \\
\hline \multirow[t]{4}{*}{$\mathrm{G}_{2}^{\mathrm{d}}$} & A \& B & 1 & CX \& S X1 to 4 & 05/31/11 & $06 / 26 / 11$ & 08/30/11 \\
\hline & & 2 & CX \& S X 1 to 4 & 07/07/11 & 08/17/11 & 08/30/11 \\
\hline & & 3 & CX \& S X1 to 4 & 08/03/11 & & 09/06/11 \\
\hline & & 4 & $\mathrm{CX} \& \mathrm{~S} X 1$ to 4 & 09/01/11 & & 10/06/11 \\
\hline \multirow[t]{4}{*}{$\mathrm{G}_{3}$} & A \& B & 1 & CX \& S X1 to 4 & $06 / 20 / 12$ & 07/18/12 & $12 / 13 / 12$ \\
\hline & & 2 & $\mathrm{CX} \& \mathrm{~S} X 1$ to 4 & 07/18/12 & $08 / 22 / 12$ & $12 / 13 / 12$ \\
\hline & & 3 & $\mathrm{CX} \& \mathrm{~S} X 1$ to 4 & $08 / 21 / 12$ & 09/18/12 & $12 / 13 / 12$ \\
\hline & & 4 & CX \& S X1 to 4 & $10 / 02 / 12$ & & $12 / 13 / 12$ \\
\hline \multirow[t]{4}{*}{$\mathrm{G}_{4}$} & A \& B & 1 & $\mathrm{CX} \& \mathrm{~S} X 1$ to 4 & 05/29/13 & & 10/08/13 \\
\hline & & 2 & $\mathrm{CX} \& \mathrm{~S} X 1$ to 4 & $06 / 25 / 13$ & & 10/08/13 \\
\hline & & 3 & CX \& S X 1 to 4 & 07/23/13 & & $10 / 08 / 13$ \\
\hline & & 4 & CX \& S X1 to 4 & 08/20/13 & & $10 / 08 / 13$ \\
\hline
\end{tabular}

\footnotetext{
${ }^{\mathrm{a}}$ The oysters used to produce the next generation are in bold.

b The letter $\mathrm{X}$ should be replaced by the name of the line either ' $\mathrm{A}$ ' or ' $\mathrm{B}$ '.

${ }^{\mathrm{c}}$ For the first deployment of the $G_{1}$, lines $A$ and $B$ were tested in the field starting on 06/15/10. For each line, the control group $C$ and the selected group $S$ were exposed to OsHV-1, and the survivors of this deployment were spawned to produce the $\mathrm{G}_{2}-\mathrm{SA} 1$ and $\mathrm{G}_{2}-\mathrm{SB} 1$ for lines A and B, respectively. The same approach was used for the second deployment, but the survivors produced the spawns $\mathrm{G}_{2}-\mathrm{SA} 2$ and $\mathrm{G}_{2}$-SB2 for lines A and B, respectively, and so on until the fourth deployment.

${ }^{\mathrm{d}}$ For the first deployment of the $\mathrm{G}_{2}$, lines A and B were tested in the field. For each line, there was a control group C and the selected group S, which had four replicate spawns (SA1 to SA4 for line A, and SB1 to SB4 for line B). The survivors of this deployment were used to produce the next generation (in bold). For the other deployments of the $\mathrm{G}_{2}$, the CA and CB of the control group, and SA1 to A4 for line A, and SB1 to SB4 for line B of the selected group were all tested at each deployment, but they were not used to produce the next generation.
} 
Table 3 Survival at the endpoint for the control (C) and selected (S) groups of each line for each deployment of each generation, and gain in survival of the S group over the C group

\begin{tabular}{|c|c|c|c|c|c|c|c|c|c|c|c|}
\hline \multirow[b]{2}{*}{ Generation } & \multirow[b]{2}{*}{ Deployment } & \multirow[b]{2}{*}{ Group } & \multicolumn{2}{|c|}{ At deployment } & \multicolumn{3}{|c|}{ Line A } & \multicolumn{3}{|c|}{ Line B } & \multirow{2}{*}{$\begin{array}{c}\text { Lines A \& B } \\
\text { Mean gain } \\
(\%)\end{array}$} \\
\hline & & & $\begin{array}{c}\text { Age } \\
\text { (months) }\end{array}$ & $\begin{array}{c}\text { Size } \\
(\mathrm{g})\end{array}$ & $\begin{array}{c}\mathrm{C} \\
(\%)\end{array}$ & $\begin{array}{l}S^{c} \\
(\%)\end{array}$ & $\begin{array}{c}\text { Gain } \\
(\%)\end{array}$ & $\begin{array}{c}\mathrm{C} \\
(\%)\end{array}$ & $\begin{array}{l}S^{C} \\
(\%)\end{array}$ & $\begin{array}{c}\text { Gain } \\
(\%)\end{array}$ & \\
\hline $\mathrm{G}_{0}$ & 1 & $\mathrm{~S}$ & 4 & 1 & \multicolumn{2}{|c|}{8.9} & & \multicolumn{2}{|c|}{22.4} & & \\
\hline \multirow[t]{5}{*}{$\mathrm{G}_{1}$} & 1 & C \& S1 & 3 & 1 & 4.0 & 16.0 & 12.0 & 13.0 & 29.3 & 16.3 & \\
\hline & 2 & C \& S2 & 4 & 3 & 1.3 & 15.0 & 13.7 & 10.3 & 17.0 & 6.7 & \\
\hline & 3 & C \& S3 & 5 & 6 & 5.0 & 63.0 & 58.0 & 18.7 & 25.7 & $7.0^{\mathrm{ns}}$ & \\
\hline & 4 & C \& S4 & 6 & 9 & 8.7 & 70.3 & 61.7 & 37.7 & 36.3 & $-1.4^{\mathrm{ns}}$ & \\
\hline & $1-4$ & $\mathrm{C} \& \mathrm{~S} 1$ to $4^{\mathrm{b}}$ & & mean & 4.7 & 41.8 & 37.1 & 19.9 & 27.1 & 7.2 & 22.2 \\
\hline \multirow[t]{5}{*}{$\mathrm{G}_{2}$} & 1 & $\mathrm{C} \& \mathrm{~S} 1$ to $4^{\mathrm{a}}$ & 4 & 1 & 17.0 & 31.6 & 14.6 & 16.3 & 50.0 & 33.7 & \\
\hline & 2 & $C \& S 1$ to $4^{a}$ & 5 & 3 & 6.7 & 46.4 & 39.7 & 17.7 & 63.6 & 45.9 & \\
\hline & 3 & $C \& S 1$ to $4^{a}$ & 6 & 5 & 5.3 & 62.8 & 57.5 & 15.7 & 56.1 & 40.4 & \\
\hline & 4 & $C \& S 1$ to $4^{a}$ & 7 & 7 & 15.0 & 80.1 & 65.1 & 23.7 & 77.6 & 53.9 & \\
\hline & $1-4$ & C \& S 1 to $4^{\mathrm{b}}$ & & mean & 11.0 & 55.2 & 44.2 & 18.3 & 61.8 & 43.5 & 43.9 \\
\hline \multirow[t]{5}{*}{$\mathrm{G}_{3}$} & 1 & $C \& S 1$ to $4^{a}$ & 3 & 1 & 2.0 & 34.5 & 32.5 & 2.7 & 54.8 & 52.1 & \\
\hline & 2 & $C \& S 1$ to $4^{a}$ & 4 & 3 & 3.0 & 35.0 & 33.0 & 2.3 & 60.2 & 57.9 & \\
\hline & 3 & $C \& S 1$ to $4^{a}$ & 5 & 7 & 21.2 & 79.5 & 58.3 & 11.9 & 79.5 & 67.6 & \\
\hline & 4 & $C \& S 1$ to $4^{a}$ & 6 & 11 & 98.7 & 98.8 & $0.1^{\mathrm{ns}}$ & 98.7 & 98.6 & $-0.1^{\mathrm{ns}}$ & \\
\hline & $1-4$ & $C \& S 1$ to $4^{b}$ & & mean $^{\mathrm{d}}$ & 8.7 & 49.7 & 41.0 & 5.6 & 64.9 & 59.3 & 50.2 \\
\hline \multirow[t]{5}{*}{$\mathrm{G}_{4}$} & 1 & $C \& S 1$ to $4^{a}$ & 3 & 1 & 6.7 & 50.6 & 43.9 & 7.2 & 59.6 & 52.4 & \\
\hline & 2 & $C \& S 1$ to $4^{a}$ & 4 & 2 & 4.3 & 61.7 & 57.4 & 5.0 & 77.8 & 72.8 & \\
\hline & 3 & $C \& S 1$ to $4^{a}$ & 5 & 2 & 5.7 & 60.9 & 55.2 & 10.5 & 62.3 & 51.8 & \\
\hline & 4 & $C \& S 1$ to $4^{a}$ & 6 & 4 & 8.7 & 88.9 & 80.2 & 10.3 & 90.9 & 80.6 & \\
\hline & $1-4$ & $\mathrm{C} \& \mathrm{~S} 1$ to $4^{\mathrm{b}}$ & & mean & 6.3 & 65.5 & 59.2 & 8.3 & 72.6 & 64.3 & 61.8 \\
\hline
\end{tabular}

\footnotetext{
${ }^{\mathrm{a}}$ The survival of the $\mathrm{S}$ group is the mean of the four replicate spawns A1 to A4 for line A and B1 to B4 for line B.

${ }^{\mathrm{b}}$ Mean survival of the four deployments within group (selected S or control C)

${ }^{\mathrm{c}}$ In bold, the oysters used to produce the next generation for the selected group, and in bold and italic, the value used to estimate the realized heritability.

${ }^{\mathrm{d}}$ No mortality observed for the last deployment of $\mathrm{G}_{3}$. It was excluded for the calculation of the mean.

${ }^{n s}$ Not significant. All other comparisons showed a significantly higher survival of the $S$ group $(\mathrm{P}<0.0001)$ within generation, deployment and line, but this is not indicated for the clarity of this table.
} 
Table 4 Logit analysis of the survival of $G_{4}$ in 2013

\begin{tabular}{lccc}
\hline \multicolumn{1}{c}{ Source } & $\mathrm{df}$ & $\chi 2$ & $\mathrm{P}$ \\
\hline group & 1 & 446.24 & $<0.0001$ \\
line & 1 & 1.81 & 0.18 \\
deployment & 3 & 13.29 & 0.0041 \\
group x line & 1 & 0.03 & 0.87 \\
group x deployment & 3 & 8.50 & 0.04 \\
line x deployment & 3 & 0.18 & 0.98 \\
line x group x deployment & 3 & 0.87 & 0.83
\end{tabular}

Slice option at the group level ${ }^{a}$

Selected group

Control group

Slice option at the deployment level $l^{b}$

Deployment 1

Deployment 2

Deployment 3

Deployment 4
3

3

1

1

1

1
70.1

$<0.0001$

2.57

0.46

${ }^{\mathrm{a}}$ Test for each group the difference in survival among the four deployments.

$\mathrm{b}$ Test for each deployment the difference in survival between the selected group and the control group. 
Table 5 Gain of survival (\% point higher than control) per generation of selection for each line and both lines according to size for oysters weighing $1 \mathrm{~g}$ or more than $3 \mathrm{~g}$ when exposed to OsHV-1

\begin{tabular}{lcccccc}
\hline \multirow{2}{*}{ Generation } & \multicolumn{3}{c}{$1 \mathrm{~g}^{\mathrm{ab}}$} & & \multicolumn{3}{c}{$>3 \mathrm{~g}^{\mathrm{ac}}$} \\
& Line A & Line B & Both lines & Line A & Line B & Both lines \\
\hline $\mathrm{G}_{1}$ & $+12.0 \%$ & $+16.3 \%$ & $+15.2 \%$ & $+59.8 \%$ & $+2.8 \%$ & $+31.3 \%$ \\
$\mathrm{G}_{2}$ & $+14.6 \%$ & $+33.7 \%$ & $+24.2 \%$ & $+61.3 \%$ & $+47.2 \%$ & $+54.3 \%$ \\
$\mathrm{G}_{3}$ & $+32.5 \%$ & $+52.1 \%$ & $+42.3 \%$ & $+58.3 \%$ & $+67.6 \%$ & $+63.0 \%$ \\
$\mathrm{G}_{4}$ & $+43.9 \%$ & $+52.4 \%$ & $+48.2 \%$ & $+80.2 \%$ & $+80.6 \%$ & $+80.4 \%$ \\
$\begin{array}{l}\text { Average per } \\
\text { generation }\end{array}$ & $+11.0 \%$ & $+13.1 \%$ & $+12.1 \%$ & $+20.1 \%$ & $+20.2 \%$ & $+20.2 \%$ \\
$\begin{array}{l}\text { Heritability } \\
\text { realized }\end{array}$ & $0.34 \pm 0.05$ & $0.52 \pm 0.03$ & $0.41 \pm 0.03$ & $0.46 \pm 0.05$ & $0.63 \pm 0.04$ & $0.52 \pm 0.03$ \\
\hline
\end{tabular}

${ }^{\mathrm{a}}$ The gain is the percentage points higher than the control. For example, when the survival of the control is $10 \%$, the survival of the selected group for the line A and after four generations of selection should be 53.9\% for oysters weighing $1 \mathrm{~g}$ when exposed to OsHV-1.

${ }^{b}$ The realized heritability was estimated using the $G_{0}$, the four $G_{1}$ deployments, and the first deployment of $\mathrm{G}_{2}, \mathrm{G}_{3}$ and $\mathrm{G}_{4}$ (oysters weighing $1 \mathrm{~g}$ ) (see Tables 2 and 3).

${ }^{c}$ The realized heritability was estimated using the $G_{0}$, the four $G_{1}$ deployments, the first deployment of $G_{2}$ and $\mathrm{G}_{3}$, and the last deployment of $\mathrm{G}_{4}$, which had a size of $4 \mathrm{~g}$. 
Table 6 Covariance analysis of shell height and oyster weight for the first deployment of $\mathrm{G}_{4}$ at endpoint in October 2013

\begin{tabular}{llcccc}
\hline \multicolumn{1}{c}{ Source } & df & MS & F & P \\
\hline Shell height & group & 1 & 0.59 & 21.16 & $<0.0001$ \\
& line & 1 & 0.01 & 0.07 & 0.79 \\
& group x line & 1 & 0.09 & 3.12 & 0.08 \\
& error & 576 & 0.03 & & \\
Oyster weight & & & & \\
& group & 1 & 4.27 & 26.89 & $<0.0001$ \\
& line & 1 & 0.01 & 0.05 & 0.83 \\
& group x line & 1 & 0.14 & 0.90 & 0.34 \\
\hline
\end{tabular}

Table 7 Variance analysis of the yield standardized for $1 \mathrm{~kg}$ of spat tested for the first deployment of $\mathrm{G}_{4}$ at endpoint in October 2013

\begin{tabular}{lcccc}
\hline \multicolumn{1}{c}{ Source } & $\mathrm{df}$ & $\mathrm{MS}$ & $\mathrm{F}$ & $\mathrm{P}$ \\
\hline group & 1 & 16.65 & 151.80 & $<0.0001$ \\
line & 1 & 0.33 & 3.06 & 0.10 \\
group x line & 1 & 0.01 & 0.03 & 0.87 \\
bag (line group) & 4 & 0.05 & 0.22 & 0.92 \\
error & 11 & 0.01 & & \\
\hline
\end{tabular}

